\title{
Metallothionein 1 negatively regulates glucose-stimulated insulin secretion and is differentially expressed in conditions of beta cell compensation and failure in mice and humans
}

\author{
Mohammed Bensellam ${ }^{1} \cdot$ Yan-Chuan Shi ${ }^{2,3} \cdot$ Jeng Yie Chan ${ }^{2,3} \cdot$ D. Ross Laybutt ${ }^{2,3} \cdot$ Heeyoung Chae ${ }^{1} \cdot$ \\ Michel Abou-Samra ${ }^{1} \cdot$ Evan G. Pappas $^{4} \cdot$ Helen E. Thomas ${ }^{4} \cdot$ Patrick Gilon $^{1} \cdot$ Jean-Christophe Jonas ${ }^{1}$
}

Received: 11 June 2019 / Accepted: 13 August 2019 / Published online: 17 October 2019

(C) Springer-Verlag GmbH Germany, part of Springer Nature 2019

\begin{abstract}
Aims/hypothesis The mechanisms responsible for beta cell compensation in obesity and for beta cell failure in type 2 diabetes are poorly defined. The mRNA levels of several metallothionein (MT) genes are upregulated in islets from individuals with type 2 diabetes, but their role in beta cells is not clear. Here we examined: (1) the temporal changes of islet $M t 1$ and $M t 2$ gene expression in mouse models of beta cell compensation and failure; and (2) the role of Mt1 and Mt2 in beta cell function and glucose homeostasis in mice.

Methods Mt1 and Mt2 expression was assessed in islets from: (1) control lean (chow diet-fed) and diet-induced obese (high-fat diet-fed for 6 weeks) mice; (2) mouse models of diabetes ( $d b / d b$ mice) at 6 weeks old (prediabetes) and 16 weeks old (after diabetes onset) and age-matched $d b /+$ (control) mice; and (3) obese non-diabetic $o b / o b$ mice (16-week-old) and age-matched $o b /+$ (control) mice. MT1E, MT1X and MT2A expression was assessed in islets from humans with and without type 2 diabetes. $M t 1-M t 2$ double-knockout (KO) mice, transgenic mice overexpressing $M t 1$ under the control of its natural promoter (Tg-Mt1) and corresponding control mice were also studied. In MIN6 cells, MT1 and MT2 were inhibited by small interfering RNAs. mRNA levels were assessed by real-time RT-PCR, plasma insulin and islet MT levels by ELISA, glucose tolerance by i.p. glucose tolerance tests and overnight fasting- $1 \mathrm{~h}$ refeeding tests, insulin tolerance by i.p. insulin tolerance tests, insulin secretion by RIA, cytosolic free $\mathrm{Ca}^{2+}$ concentration with Fura-2 leakage resistant (Fura-2 LR), cytosolic free $\mathrm{Zn}^{2+}$ concentration with Fluozin-3, and NAD(P)H by autofluorescence.

Results $M t 1$ and $M t 2$ mRNA levels were reduced in islets of murine models of beta cell compensation, whereas they were increased in diabetic $d b / d b$ mice. In humans, $M T 1 X$ mRNA levels were significantly upregulated in islets from individuals with type 2 diabetes in comparison with non-diabetic donors, while $M T 1 E$ and $M T 2 A$ mRNA levels were unchanged. Ex vivo, islet $M t 1$ and $M t 2$ mRNA and MT1 and MT2 protein levels were downregulated after culture with glucose at 10-30 mmol/1 vs 2$5 \mathrm{mmol} / \mathrm{l}$, in association with increased insulin secretion. In human islets, mRNA levels of MT1E, MT1X and MT2A were downregulated by stimulation with physiological and supraphysiological levels of glucose. In comparison with wild-type (WT) mice, Mt1-Mt2 double-KO mice displayed improved glucose tolerance in association with increased insulin levels and enhanced insulin release from isolated islets. In contrast, isolated islets from Tg-Mt1 mice displayed impaired glucose-stimulated insulin secretion (GSIS). In both Mt1-Mt2 double-KO and Tg-Mt1 models, the changes in GSIS occurred despite similar islet
\end{abstract}

Electronic supplementary material The online version of this article (https://doi.org/10.1007/s00125-019-05008-3) contains peer-reviewed but unedited supplementary material, which is available to authorised users.

Mohammed Bensellam

mohammed.bensellam@uclouvain.be

Jean-Christophe Jonas

jean-christophe.jonas@uclouvain.be

1 Pôle d'endocrinologie, Diabète et Nutrition, Institut de Recherche Expérimentale et Clinique, Université catholique de Louvain, Avenue Hippocrate 55 - B1.55.06, B-1200 Brussels, Belgium
2 Garvan Institute of Medical Research, Sydney, New South Wales, Australia

3 St Vincent's Clinical School, UNSW Sydney, Sydney, New South Wales, Australia

4 St Vincent's Institute, Department of Medicine, St Vincent's Hospital, The University of Melbourne, Fitzroy, Victoria, Australia 


\section{Research in context}

\section{What is already known about this subject?}

- The mechanisms responsible for beta cell compensation in obesity and beta cell failure in type 2 diabetes are poorly defined

- Several metallothionein genes are upregulated in islets from individuals with type 2 diabetes but their role in beta cells is not clear

What is the key question?

- Do changes in Mt1 and/or Mt2 gene expression play a role in the modulation of beta cell function?

What are the new findings?

- Mt1 and Mt2 mRNA levels are downregulated in the islets of obese mice that can compensate for insulin resistance by increasing insulin secretion, whilst they are upregulated in the islets of mouse models of diabetes that fail to compensate

- Mt1 inhibition enhances glucose-stimulated insulin secretion and improves glucose tolerance in mice, whereas its overexpression attenuates the secretory response

- Mt1 modulation of beta cell function does not involve classical pathways, such as changes in glucose metabolism, intracellular $\mathrm{Ca}^{2+}$, intracellular $\mathrm{Zn}^{2+}$ and insulin content

\section{How might this impact on clinical practice in the foreseeable future?}

- Our findings suggest that Mt1 is a key negative regulator of beta cell function. The inhibition of Mt1 may represent an attractive therapeutic target to augment insulin secretion in type 2 diabetes

insulin content, rises in cytosolic free $\mathrm{Ca}^{2+}$ concentration and NAD(P)H levels, or intracellular $\mathrm{Zn}^{2+}$ concentration vs WT mice. In MIN6 cells, knockdown of MT1 but not MT2 potentiated GSIS, suggesting that Mt1 rather than Mt2 affects beta cell function. Conclusions/interpretation These findings implicate Mt1 as a negative regulator of insulin secretion. The downregulation of $M t 1$ is associated with beta cell compensation in obesity, whereas increased Mt1 accompanies beta cell failure and type 2 diabetes.

Keywords Beta cell compensation · Beta cell failure · Glucose-stimulated insulin secretion · Islets · Obesity · Type 2 diabetes

$\begin{array}{ll}\text { Abbreviations } \\ \text { BAT } & \text { Brown adipose tissue } \\ \text { EDL } & \text { Extensor digitorum longus } \\ \text { ER } & \text { Endoplasmic reticulum } \\ \lambda_{\text {ex/em }} & \text { Excitation/emission wavelength } \\ \text { FCCP } & \text { Carbonyl cyanide } \\ & \text { 4-(trifluoromethoxy)phenylhydrazone } \\ \text { Fura-2 LR } & \text { Fura-2 leakage resistant } \\ \text { GSIS } & \text { Glucose-stimulated insulin secretion } \\ \text { HFD } & \text { High-fat diet } \\ \text { KO } & \text { Knockout } \\ \text { LCM } & \text { Laser-capture microdissection } \\ \text { MT } & \text { Metallothionein } \\ \text { SiRNA } & \text { Small interfering RNA } \\ \text { Tg-Mt1 } & \text { Transgenic mice overexpressing } \\ & M t 1 \text { under the control of its natural promoter } \\ \text { TPEN } & N, N, N^{\prime}, N^{\prime} \text {-tetrakis(2-pyridinylmethyl)- } \\ & 1,2 \text {-ethanediamine } \\ \text { WAT } & \text { White adipose tissue }\end{array}$

$\begin{array}{ll}\text { WT } & \text { Wild-type } \\ {\left[\mathrm{Zn}^{2+}\right]_{\mathrm{i}}} & \text { Intracellular free } \mathrm{Zn}^{2+} \text { levels }\end{array}$

\section{Introduction}

Type 2 diabetes results from the complex interplay of genetic and environmental risk factors, among which obesity plays a predominant role. Interestingly, most obese individuals compensate for insulin resistance by increasing insulin secretion, thereby maintaining normoglycaemia at the price of hyperinsulinaemia. However, this compensation can be sidestepped by a phase of decompensation in which beta cells fail to uphold an adequate secretory response [1-3]. This leads to hyperglycaemia and subsequent glucotoxic alterations of beta cell mass and function $[4,5]$. Identifying genes involved in beta cell compensation in obesity, and in beta cell failure in 
type 2 diabetes may provide new insights into beta cell pathophysiology and reveal novel therapeutic targets to preserve beta cell function in individuals with (pre) type 2 diabetes.

Metallothioneins (MTs) are a family of low molecular mass, cysteine-rich, metal-binding proteins, the (patho)physiological functions of which have not been fully characterised. Their predominant roles are heavy metal detoxification, metal ion (including zinc) homeostasis, and the regulation of cellular redox status and antioxidant defences. Among the four different murine genes encoding MTs, $M t 1$ and $M t 2$ are expressed ubiquitously, Mt3 is mainly expressed in neurons and Mt4 is expressed in squamous epithelium cells. In humans, in addition to MT2 (also known as MT2A), MT3 and MT4, there are eight MT1 isoforms for a total of 11 functional MT genes [6, 7]. Interestingly, polymorphisms in MT1A and MT2A have been associated with increased risk for type 2 diabetes and diabetic complications [8-10]. Moreover, MT1E, MT1M, MT1X and $M T 2 A$ mRNA levels were significantly upregulated in islets obtained by laser-capture microdissection (LCM) of pancreatic sections from type 2 diabetes donors [11]. However, the role of MTs in the pathophysiology of type 2 diabetes remains unclear. We, therefore, verified whether changes in $M t 1$ and/or $M t 2$ gene expression plays a role in the modulation of beta cell function.

\section{Methods}

Reagents Fura-2 leakage resistant (Fura-2 LR), diazoxide (Dz), carbonyl cyanide 4-(trifluoromethoxy)phenylhydrazone (FCCP) and $\mathrm{ZnCl}_{2}$ were from Sigma (St Louis, MI, USA). $N, N, N^{\prime}, N^{\prime}-$ tetrakis(2-pyridinylmethyl)-1,2-ethanediamine (TPEN) was from Abcam (Cambridge, UK). Fluozin-3, control nontargeting small interfering RNA (siRNA), ON-TARGETplus SMARTpool siRNA and DharmaFECT3 (transfection reagent) were from Thermo Fisher Scientific (Lafayette, CO, USA).

Mice Six- and 16-week-old male and female C57BL/KsJ $d b$ / $d b$ mice and age-matched lean control mice (C57BL/KsJ), 16week-old male and female C57BL/6J ob/ob mice and agematched lean control mice, and the 16-week-old wild-type (WT) male mice (C57BL/6JAusb) used in diet-induced obesity experiments were from the Garvan Institute breeding colonies (Australian BioResources, Moss Vale, NSW, Australia). Male Mt1-Mt2 double-knockout (KO) mice at 4-5 months of age $\left(129 \mathrm{~S} 7 / \mathrm{SvEvBrd}-M t 1^{\mathrm{tm} 1 \mathrm{Bri}} M t 2^{\mathrm{tm} 1 \mathrm{Bri}} / \mathrm{J}\right.$; herein referred to as KO mice) and their sex- and age-matched controls (129S1/ SvImJ) originated from the Jackson Laboratory (Bar Harbor, MA, USA). Male transgenic mice overexpressing $M t 1$ under the control of its natural promoter at 3 and 9 months of age (B6.Cg-Tg(Mt1)174Bri/J; referred to as Tg-Mt1) and their sex- and age-matched controls (C57BL/6 J) were also from the Jackson Laboratory. All animals were bred in the local animal facility of the health sciences sector at UCLouvain.
Mice were housed under a controlled temperature of $22^{\circ} \mathrm{C}$ and a $12 \mathrm{~h}$ light cycle, with ad libitum access to water and chow ( $8 \%$ energy from fat, $21 \%$ energy from protein and $71 \%$ energy from carbohydrate [wt/wt]; $10.9 \mathrm{~kJ} / \mathrm{g}$; Gordon's Specialty Stock Feeds, Yanderra, NSW, Australia) or a highfat diet (HFD; 23\% energy from fat, 19.4\% energy from protein and $57.6 \%$ energy from carbohydrate and fibres [wt/wt for all]; $20.1 \mathrm{~kJ} / \mathrm{g}$; catalogue no. SF03-020; Specialty Feeds, Glen Forest, WA, Australia). Mice were randomly assigned to experimental groups using an odd/even number method by unblinded experimenters. All experiments were approved by the Institutional Committee on Animal Experimentation of the Health Sciences Sector at UCLouvain (Project 2013/UCL/ $\mathrm{MD} / 016)$ and the Garvan Institute/St Vincent's Hospital Animal Experimentation Ethics Committee.

Human islets Human islets were obtained from 24 non-diabetic and 12 diabetic individuals at the Tom Mandel Islet Transplant Program, Melbourne [12]. Human islets were isolated from heart-beating, brain-dead donors and approved for use under the ethics reference HREC011/04 (St Vincent's Hospital Human Research Ethics Committee). Characteristics of donors and islet preparations are listed in the electronic supplementary material (ESM) Table 1. To evaluate the effects of glucose on MT gene expression, islets were obtained from three nondiabetic donors through the JDRF award 31-2008-416 (European Consortium for Islet Transplantation [ECIT] Islet for Basic Research program) and approved for use under the ethics reference B403/2017/05JUL/355 (Comité d'éthique hospitalo-facultaire Saint-Luc, UCLouvain). Characteristics of these donors are indicated in ESM Table 2. Written informed consent was obtained from next of kin and all experiments were performed in accordance with relevant guidelines and regulations.

Glucose and insulin tolerance tests Intraperitoneal (i.p.) glucose tolerance tests (i.p.GTTs) and fasting-refeeding tests were performed on overnight-fasted mice and i.p. insulin tolerance tests (i.p.ITTs) on $4 \mathrm{~h}$-fasted mice. For fastingrefeeding tests, blood glucose levels were measured in fasted mice and $1 \mathrm{~h}$ after refeeding. For i.p.GTTs and i.p.ITTs, mice were injected i.p. with glucose ( $2 \mathrm{~g} / \mathrm{kg}$ of body weight) or insulin $(0.75 \mathrm{U} / \mathrm{kg}$ of body weight; Actrapid, Novo Nordisk, Bagsværd, Denmark) and blood glucose levels were measured at the indicated time points using a FreeStyle Precision Neo glucometer (Abbott, Wavre, Belgium).

Tissue collection and histological analysis Mice were killed by cervical dislocation and trunk blood collected and centrifuged for measurement of plasma insulin levels by ultra-sensitive ELISA (Crystal Chem, Downers Grove, IL, USA). The pancreas, liver, white adipose tissue (WAT) fat pads (epidydimal, retroperitoneal and inguinal), interscapular brown adipose 
tissue (BAT), skeletal muscles of the right leg (tibialis anterior, extensor digitorum longus [EDL], gastrocnemius and soleus) and heart of each animal were dissected, weighed, and frozen or fixed in $4 \%$ (wt/vol.) paraformaldehyde for $24 \mathrm{~h}$ at $4{ }^{\circ} \mathrm{C}$ and embedded in paraffin for further histological analysis. Liver and epidydimal fat pad sections were counter stained with haematoxylin and eosin (H\&E) to assess morphology. Adipocyte size was analysed using Visiopharm software (Author module, Version 6.4.1; Hørsholm, Denmark). Insulin and glucagon immunostaining of pancreatic sections was performed as previously described $[13,14]$. Beta cell mass was computed based on the relative cross-sectional beta cell area and pancreas weight. Three pancreatic sections at three different levels were analysed for each mouse. Pancreatic sections immunoprobed for insulin, glucagon and a nuclear stain (DAPI) were scanned using the panoramic 250 Flash III digital slide scanner (3DHISTECH, Budapest, Hungary) and analysed with Visiopharm.

Islet isolation and culture Islets were isolated by collagenase digestion, separated by density gradient centrifugation and handpicked under a stereomicroscope. Islets were cultured in standard RPMI medium (Invitrogen, Carlsbad, CA, USA) supplemented with $2 \mathrm{mmol} / \mathrm{l}$ glutamine, $5 \mathrm{~g} / \mathrm{l} \mathrm{BSA}, 100$ $\mathrm{U} / \mathrm{ml}$ penicillin and $100 \mu \mathrm{g} / \mathrm{ml}$ streptomycin.

Cell culture and treatment MIN6 cells (passage 26-43; mycoplasma negative), originally provided by J. I. Miyazaki (Osaka University Medical School, Osaka, Japan) [15], were grown in Dulbecco's modified Eagle's medium (DMEM; Invitrogen) containing $25 \mathrm{mmol} / \mathrm{lg}$ glucose, $10 \mathrm{mmol} / \mathrm{l} \mathrm{HEPES,} \mathrm{10 \%} \mathrm{FCS} \mathrm{(vol./}$ vol.), $50 \mathrm{U} / \mathrm{ml}$ penicillin and $50 \mu \mathrm{g} / \mathrm{ml}$ streptomycin. Cells were transfected with $100 \mathrm{nmol} / 1$ control, Mt1 or Mt2 siRNA using DharmaFECT 3 transfection reagent $24 \mathrm{~h}$ before experiments.

Glucose-stimulated insulin secretion (GSIS) tests Isolated islets in batches of five, or MIN6 cells seeded in 24-well plates at $2 \times 10^{5}$ cell per well, were preincubated for $1 \mathrm{~h}$ in KRB buffer (120 mmol/1 NaCl, $4.8 \mathrm{mmol} / 1 \mathrm{KCl}, 2.5 \mathrm{mmol} / 1 \mathrm{CaCl}_{2}$, $1.2 \mathrm{mmol} / 1 \mathrm{MgCl}_{2}, 24 \mathrm{mmol} / 1 \mathrm{NaHCO}_{3}$ and $1 \mathrm{~g} / \mathrm{l} \mathrm{BSA}$ ) containing $3 \mathrm{mmol} / \mathrm{l}$ glucose and then incubated for $1 \mathrm{~h}$ in KRB buffer containing $3 \mathrm{mmol} / \mathrm{l}, 15 \mathrm{mmol} / \mathrm{l}$ or $30 \mathrm{mmol} / \mathrm{l}$ glucose. At the end of the incubation, the buffer was collected for measurement of insulin by RIA, and islets were collected and disrupted by sonication in $10 \mathrm{mmol} / 1$ Tris, $0.2 \mathrm{~mol} / 1 \mathrm{NaCl}$ and $10 \mathrm{mmol} / \mathrm{l} \mathrm{EDTA}$ for measurement of their DNA and insulin content. All secretion experiments were carried out in duplicate.

Live-cell imaging $\mathrm{NAD}(\mathrm{P}) \mathrm{H}$ autofluorescence (excitation/ emission wavelength $\left.\left[\lambda_{\text {ex/em }}\right], 360 / 470 \mathrm{~nm}\right)$ was measured every $5 \mathrm{~s}$ and expressed as the percentage of the fluorescence level measured after 15-20 min of treatment with $10 \mu \mathrm{mol} / \mathrm{l}$ FCCP in KRB buffer containing $30 \mathrm{mmol} / \mathrm{l}$ glucose. For measurements of intracellular $\mathrm{Ca}^{2+}$ concentrations, islets were loaded for $2 \mathrm{~h}$ with $2 \mu \mathrm{mol} / \mathrm{l}$ Fura-2 LR acetoxymethyl ester and the fluorescence ratio $\left(\lambda_{\mathrm{ex} / \mathrm{em}}, 340 / 510\right.$ to $\left.380 / 510 \mathrm{~nm}\right)$ was measured every $5 \mathrm{~s}$. For measurements of intracellular free $\mathrm{Zn}^{2+}$ levels $\left(\left[\mathrm{Zn}^{2+}\right]_{\mathrm{i}}\right)$, islets were loaded for $2 \mathrm{~h}$ with $2 \mu \mathrm{mol} / 1$ Fluozin-3 acetoxymethyl ester and fluorescence $\left(\lambda_{\text {ex/em }}, 490 / 510 \mathrm{~nm}\right.$ ) was measured every $10 \mathrm{~s}$. TPEN (a zinc chelator) was used as a negative control to lower $\left[\mathrm{Zn}^{2+}\right]_{\mathrm{i}}$ and used at $50 \mu \mathrm{mol} / \mathrm{l}$. Islets from control and $\mathrm{KO} / \mathrm{Tg}-\mathrm{Mt} 1$ mice were simultaneously perifused side by side with KRB buffer continuously gassed with $5 \% \mathrm{CO}_{2}$ air mix to maintain $\mathrm{pH} 7.4$ at a flow rate of $1 \mathrm{ml} / \mathrm{min}$ at $37^{\circ} \mathrm{C}$ on the stage of an inverted microscope.

RNA analysis Total RNA was extracted and reverse transcribed as previously described $[16,17]$. Real-time RT-PCR was performed using the SYBR Green method and a 7900HT RealTime PCR System (Applied Biosystems, Foster City, CA, USA) or a CFX96 optical cycler detection system (Bio-Rad, Hercules, CA, USA). Primer sequences are listed in ESM Table 3. The value obtained for a specific gene product was normalised to the control gene cyclophilin A or TBP and expressed as fold change of the value in the control condition. TaqMan assays were used to assess the mRNA levels of MT1E (Hs01938284_g1), MT1X (Hs00745167_sH), MT2A (Hs02379661_g1) and the control gene 18S rRNA (Hs03003631_g1) in human islets from control and type 2 diabetes donors (Applied Biosystems). AmpliTaq Gold reagents (Thermo Fisher Scientific) were used on a Light Cycler 480 Instrument II (Roche, Risch-Rotkreuz, Switzerland).

Protein analysis Islet MT1 and MT2 protein levels were quantified by ELISA (Frontier Institute, Ishikari, Japan). Absorbance values were normalised to total protein content measured with the Pierce BCA Protein Assay Kit (Thermo Fisher Scientific).

Statistical analysis Results are means \pm SEM for the indicated number of experiments. Statistical significance was assessed by unpaired two-tailed Student's $t$ test, one-way ANOVA with a Newman-Keuls post hoc test, or two-way ANOVA with a Bonferroni post hoc test.

\section{Results}

Mt1 and Mt2 mRNA levels were differentially regulated between conditions of beta cell compensation and failure Islet $M t 1$ and Mt2 mRNA levels were markedly downregulated in mice fed for 6 weeks with a HFD vs a chow diet. This was associated with increased body-weight gain and plasma insulin levels (compensation) (Fig. 1a,b and ESM Fig. 1). Similarly, islet $M t 1$ and $M t 2$ mRNA levels were significantly 

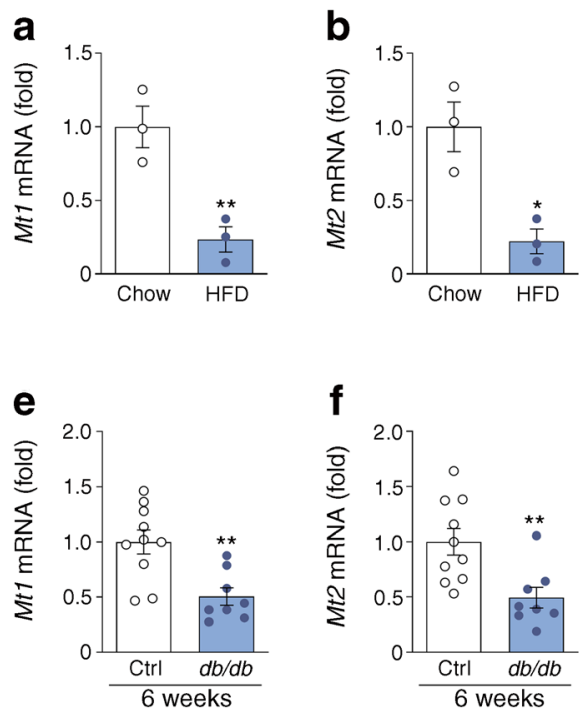

Fig. $1 M t 1$ and Mt2 mRNA levels are downregulated in the islets of obese compensating mice and upregulated in the islets of decompensating diabetic mice. $(\mathbf{a}-\mathbf{h})$ Changes in the mRNA levels of $M t 1$ and $M t 2$ in the islets of $(\mathbf{a}, \mathbf{b})$ chow-fed and HFD-fed WT mice, $(\mathbf{c}, \mathbf{d})$ control and $o b / o b$ mice at 16 weeks of age, $(\mathbf{e}, \mathbf{f})$ control and $d b / d b$ mice at 6 weeks of age,

downregulated in 16-week-old ob/ob mice (Fig. 1c,d), a model of successful beta cell compensation [17, 18], vs control mice. In $d b / d b$ mice, which progress from successful beta cell compensation to beta cell failure between 6 and 16 weeks of age [17], islet Mt1 and Mt2 mRNA levels were downregulated in 6week-old mice (Fig. 1e,f) and upregulated in 16-week-old mice (Fig. 1g,h). These results reveal that, in vivo, beta cell compensation is associated with $M t 1$ and $M t 2$ downregulation, whereas beta cell failure is associated with $M t 1$ and $M t 2$ upregulation.

\section{Glucose stimulation downregulated the expression of $M t 1$} and Mt2 WT mouse islets were cultured at various glucose concentrations, ranging from low, non-stimulating concentrations $(2-5 \mathrm{mmol} / \mathrm{l})$ to the optimal concentration for culture of rodent islets $(10 \mathrm{mmol} / \mathrm{l})$ to a very high glucose concentration (30 mmol/1) $[16,19,20] . M t 1$ and Mt2 mRNA and MT1/2 protein levels were markedly downregulated after culture at glucose at $10 \mathrm{mmol} / \mathrm{l}$ vs 2 and $5 \mathrm{mmol} / \mathrm{l}$, with little or no further decrease at $30 \mathrm{mmol} / \mathrm{l}$ vs $10 \mathrm{mmol} / \mathrm{l}$ glucose (Fig. 2a-c). These effects were anti-paralleled by the stimulation of insulin secretion and the upregulation of the antioxidant genes Mt3, Srxn1 and Gpx2 (Fig. 2d-g). These findings show that, compared with other antioxidant genes, $M t 1$ and $M t 2$ have a specific gene expression pattern in response to glucose stimulation. They also show an ex vivo association between islet Mt1 and Mt2 downregulation and the stimulation of insulin secretion.

MT1X mRNA levels were upregulated in human islets from individuals with type 2 diabetes and were affected by glucose stimulation MT1E, MT1X and MT2A were the most upregulated MT genes in islets obtained by LCM from pancreases of
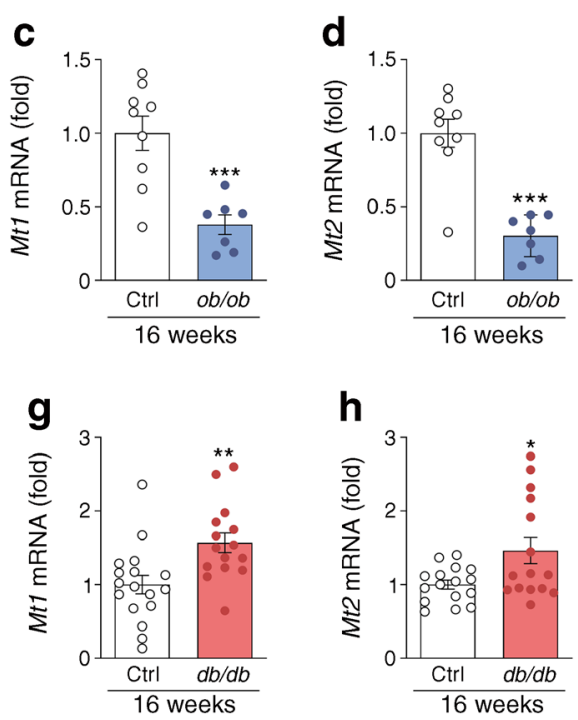

and $(\mathbf{g}, \mathbf{h})$ control and $d b / d b$ mice at 16 weeks of age. Data are means \pm SEM. (a, b) $n=3,(\mathbf{c}, \mathbf{d}) n=7-9,(\mathbf{e}, \mathbf{f}) n=8-10,(\mathbf{g}, \mathbf{h}) n=15-17$ animals per group. $* p<0.05$, ** $p<0.01$, ***p $<0.001$ vs chow-fed or control mice, unpaired two-tailed Student's $t$ test. Ctrl, control

individuals with type 2 diabetes vs islets from non-diabetic donors [11]. Among them, MT1X was the only isoform showing significantly upregulated mRNA levels in islets isolated from type 2 diabetes vs non-diabetic donors. Besides, MTIX displayed higher mRNA levels than MT1E and MT2A in islets isolated from non-diabetic donors (Fig. 3a-d). When islets from non-diabetic donors were cultured in the presence of a low, non-stimulating glucose concentration $(2.2 \mathrm{mmol} / \mathrm{l})$, the optimal glucose concentration for culture of human islets (5.5 mmol/l), a high glucose concentration $(11.1 \mathrm{mmol} / \mathrm{l})$ and a very high glucose concentration $(22 \mathrm{mmol} / \mathrm{l})$ [21, 22], MT1E, MTIX and MT2A mRNA levels were all downregulated between treatment with $2.2 \mathrm{mmol} / 1$ and $11.1 \mathrm{mmol} / \mathrm{lglu}-$ cose, while, with $22 \mathrm{mmol} / 1$ glucose, MT1E and MT1X mRNA levels returned to a similar level as with $5.5 \mathrm{mmol} / \mathrm{l}$ glucose (Fig. 3e-g). In parallel, treatment with glucose at 11.1 and $22 \mathrm{mmol} / \mathrm{l}$ significantly increased insulin secretion during culture vs treatment with 2.2 and $5.5 \mathrm{mmol} / \mathrm{l}$ glucose (Fig. $3 \mathrm{~h}$ ).

These results show that MTIX upregulation is associated with beta cell failure in human type 2 diabetes. They also reveal a specific gene expression pattern of human MT genes in response to glucose stimulation that partly resembles that of $M t 1$ and $M t 2$ in mouse islets.

Deletion of $M t 1 / M t 2$ improved glucose tolerance The potential role of $M t 1$ and/or Mt2 in the modulation of glucose homeostasis and beta cell function was investigated in a global Mt1-Mt2 double-KO mouse model [23]. Compared with WT mice, KO mice displayed higher body weight and daily food intake (ESM Fig. 2a,b). They also showed increased liver weight (ESM Fig. 2c) without macroscopical or histological 

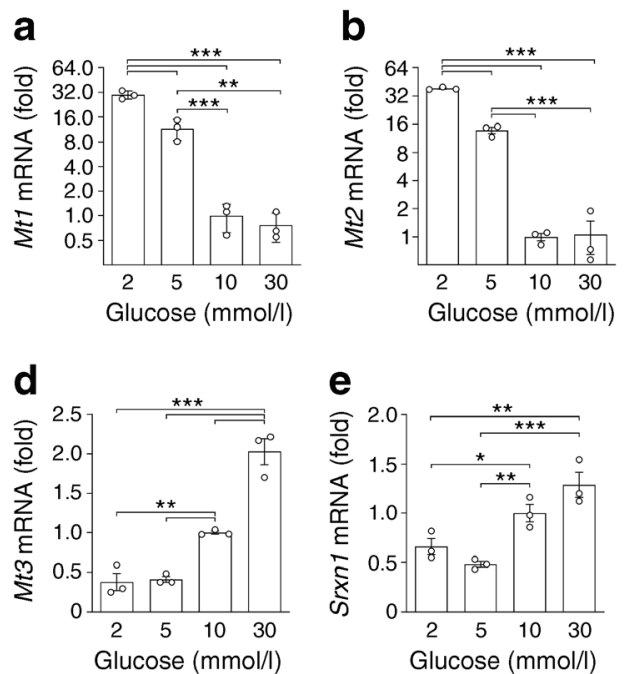

Fig. 2 Mt1 and Mt2 mRNA and MT1/MT2 protein levels are downregulated by glucose stimulation in a concentration-dependent manner. Isolated islets from WT mice were cultured for $24 \mathrm{~h}$ (for mRNA analysis) or $48 \mathrm{~h}$ (for protein analysis) in the presence of increasing glucose concentrations: $2 \mathrm{mmol} / 1,5 \mathrm{mmol} / 1,10 \mathrm{mmol} / 1$ and $30 \mathrm{mmol} / 1$. (a-c) Changes in mRNA levels of (a) Mt1 and (b) $M t 2$, and (c) MT1/MT2

signs of steatosis (ESM Fig. 2d), and increased weight of different leg muscles, including tibialis anterior, EDL and gastrocnemius (ESM Fig. 2e-g). However, soleus muscle and heart weights were similar (ESM Fig. 2h,i). Interestingly, the weight of epidydimal, inguinal and retroperitoneal fat pads and the sum of the three fat pads (WAT), thereof, were reduced in KO mice (ESM Fig. 2j-m), whereas BAT weight was similar between KO and WT mice (ESM Fig. 2n). Histological
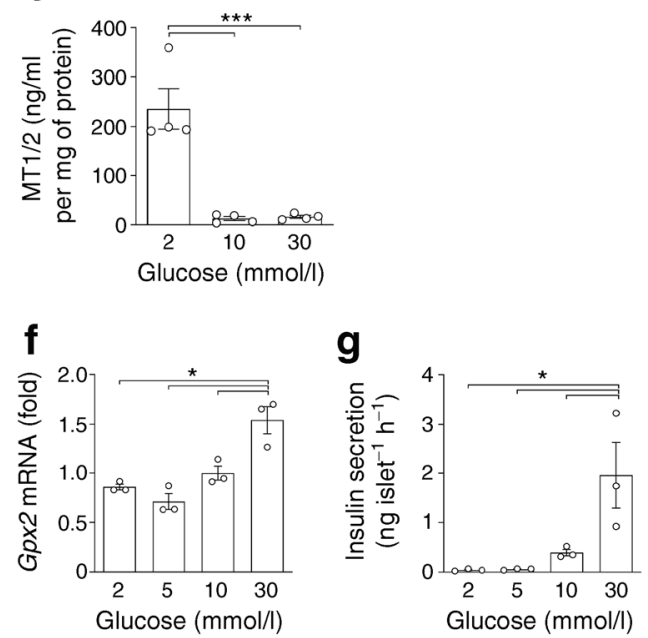

protein levels. (d-g) Changes in mRNA levels of (d) Mt3, (e) Srxn1 and (f) Gpx2 and (g) in insulin secretion. Changes in mRNA levels were normalised to cyclophilin A and expressed relative to levels with treatment with $10 \mathrm{mmol} / 1$ glucose. Data are means \pm SEM of $n=3-4$ experiments. $* p<0.05, * * p<0.01, * * * p<0.001$, one-way ANOVA with Newman-Keuls post hoc test

sections of epidydimal fat pads also revealed reduced adipocyte surface in KO mice (ESM Fig. 2o,p).

Fed blood glucose levels were similar in KO and WT mice (Fig. 4a), overnight-fasted blood glucose levels were slightly higher in $\mathrm{KO}$ mice (Fig. $4 \mathrm{~b}$ ) and fed and fasted plasma insulin levels were not significantly different (Fig. 4c,d). Interestingly, glucose tolerance during i.p.GTT was markedly improved in $\mathrm{KO}$ mice, together with significantly increased plasma insulin
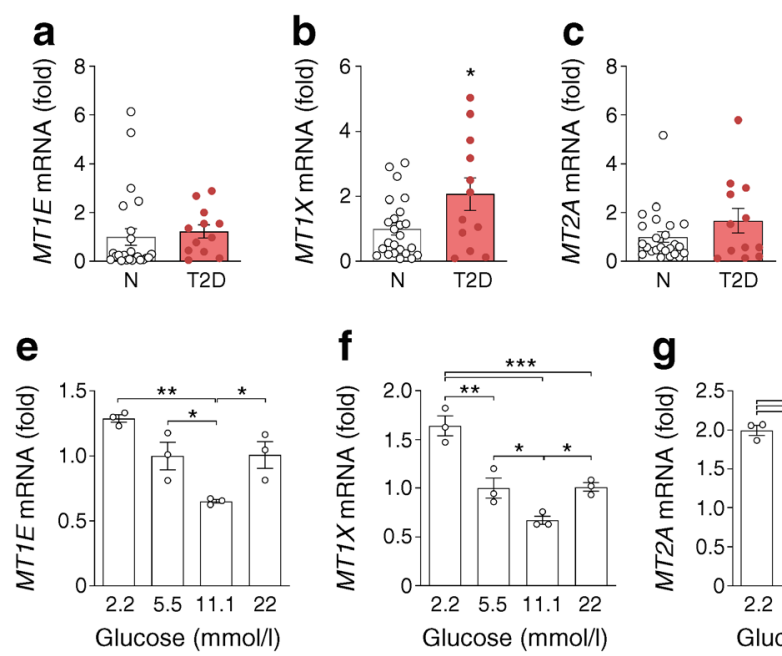

Fig. 3 MTIX mRNA levels are upregulated in the islets of human diabetic donors and MT gene isoforms are affected by glucose stimulation. (a-c) Changes in the mRNA levels of (a) MT1E, (b) MTIX and (c) MT2A in the islets of non-diabetic individuals $(\mathrm{N})$ and type 2 diabetic donors (T2D). The mRNA levels of each gene were normalised to 18S RNA. (d) Comparison of the mRNA levels of MTIE, MTIX and MT2A in the islets of non-diabetic individuals. The mRNA levels of each gene were normalised to 18S RNA and the absolute ratios compared. (e-h) Human islets from non-diabetic donors were cultured for $24 \mathrm{~h}$ in the presence of
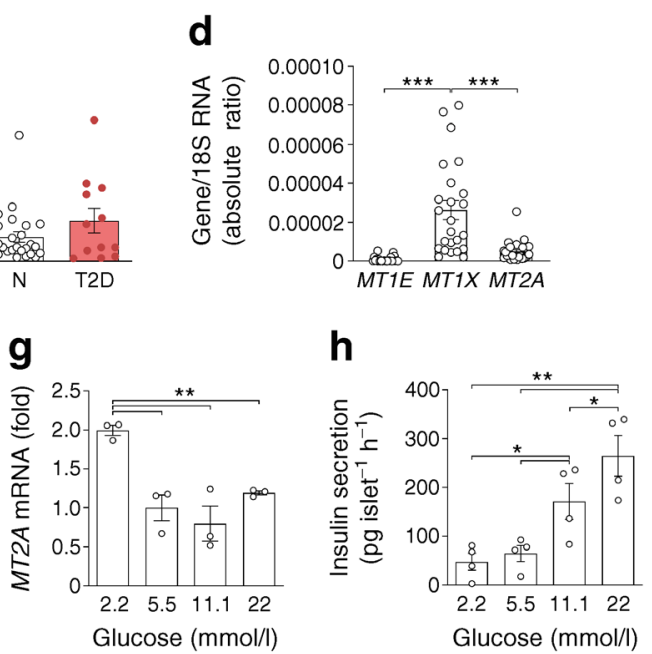

increasing glucose concentrations. (e-g) Changes in the mRNA levels of (e) $M T 1 E$, (f) $M T 1 X$ and (g) MT2A during culture. The mRNA levels of each gene were normalised to $T B P$ and expressed relative to levels with treatment with $5.5 \mathrm{mmol} / \mathrm{l}$ glucose. (h) Changes in insulin secretion during culture. Data are means $\pm \mathrm{SEM}$; (a-d) $n=24$ non-diabetic and $n=12$ type 2 diabetic donors; (e-h) $n=3-4$ experiments. * $p<0.05$, ** $p<0.01$, $* * * p<0.001$ vs non-diabetic donors or as shown; in (a-c), unpaired twotailed Student's $t$ test; in (d-h), one-way ANOVA with Newman-Keuls post hoc test 

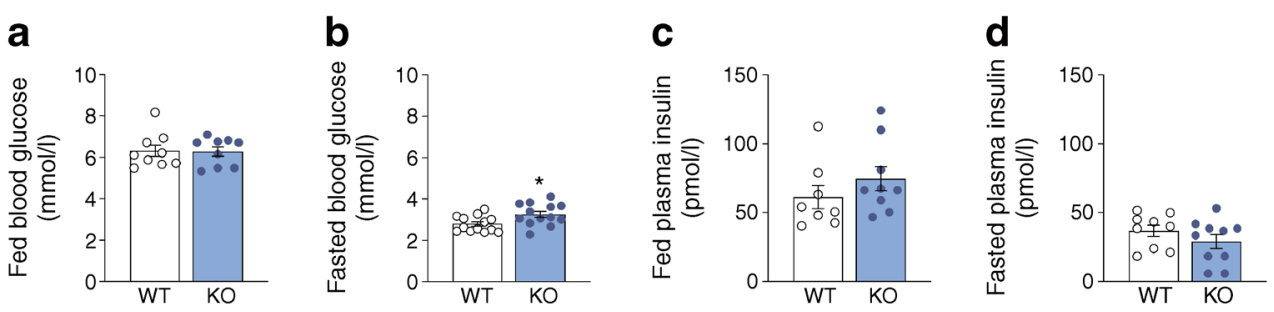

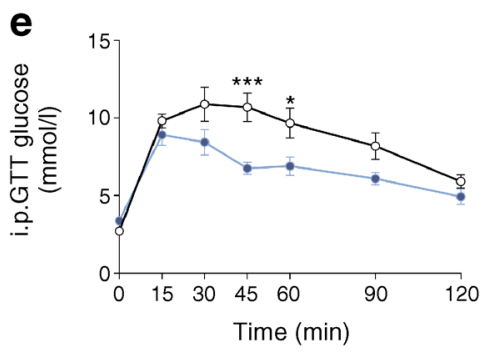

f
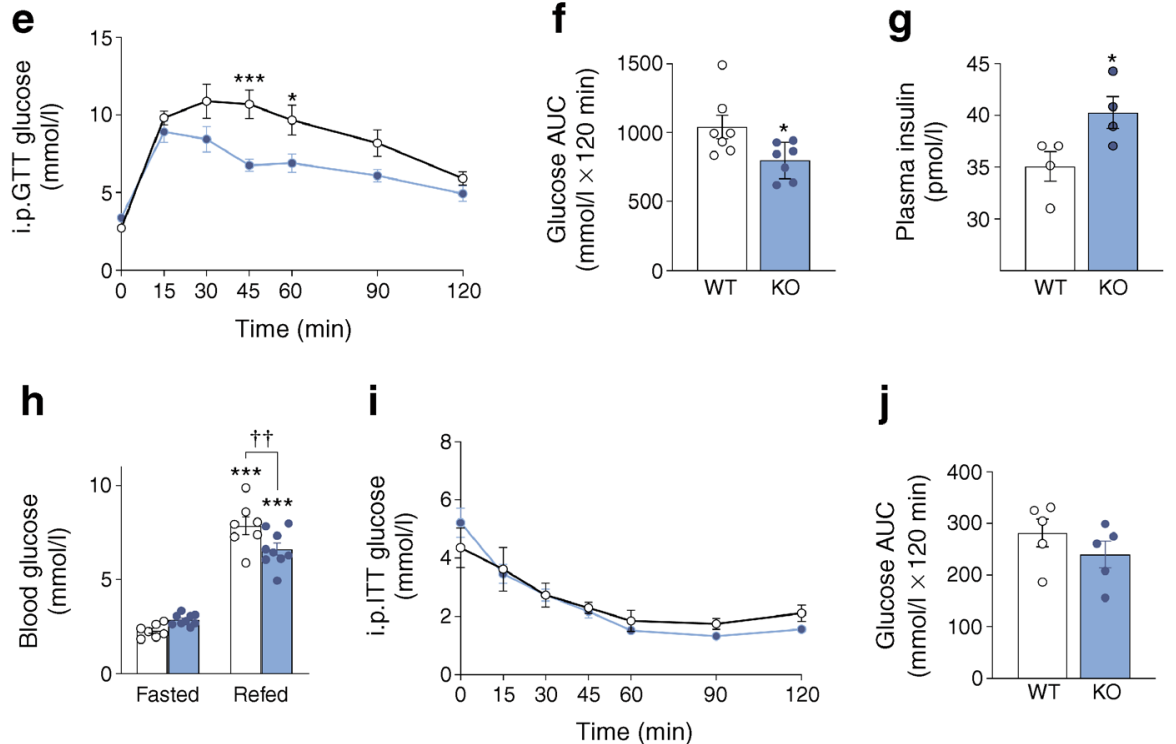

j

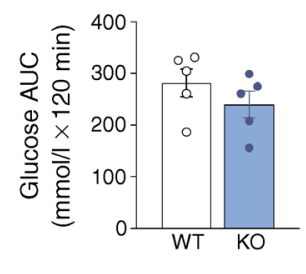

Fig. 4 Mt1-Mt2 deletion improved glucose tolerance in vivo. (a-d) Changes in (a) fed and (b) fasted blood glucose levels, and (c) fed and (d) fasted plasma insulin levels in WT and KO mice. (e) Changes in blood glucose levels and (f) AUC during an i.p.GTT in overnight-fasted WT and KO mice. (g) Plasma insulin levels 30 min following i.p.GTT. (h) Changes in blood glucose levels in WT and KO mice at the fasted state and $1 \mathrm{~h}$ after refeeding. (i) Changes in blood glucose levels and (j) AUC

levels (30 min following i.p.GTT) (Fig. 4e-g). Similarly, during an overnight fasting $/ 1 \mathrm{~h}$ refeeding test, blood glucose levels after refeeding were lower in KO mice (Fig. 4h). On the other hand, insulin sensitivity during i.p.ITT was similar in $\mathrm{KO}$ and WT mice (Fig. 4i,j). Together, these findings suggest that $M t 1-$ $M t 2$ deletion leads to improved glucose tolerance due to increased insulin secretion rather than changes in insulin action.

MT deletion potentiated GSIS The mechanism underlying improved glucose tolerance in $\mathrm{KO}$ mice was further investigated in isolated islets. In WT islets, MT1/2 protein levels were expressed under control culture conditions and upregulated by treatment with $\mathrm{ZnCl}_{2}$ (a potent inducer of MT expression). In contrast, MT1/2 proteins were not detected in $\mathrm{KO}$ islets, even after treatment with $\mathrm{ZnCl}_{2}$, confirming the lack of $M t 1-M t 2$ expression (Fig. 5a). Interestingly, GSIS was potentiated in $\mathrm{KO}$ vs WT islets after acute stimulation with $15 \mathrm{mmol} / \mathrm{lglu}-$ cose, and to a stronger extent after stimulation with $30 \mathrm{mmol} / \mathrm{l}$ glucose (Fig. 5b), while islet insulin content was unchanged in KO vs WT mice (Fig. 5c). In agreement, MT1 but not MT2 knockdown in MIN6 cells potentiated GSIS (Fig. 5d-f), during an i.p.ITT in 4 h-fasted WT and KO mice. WT, white bars/circles; KO mice, blue bars/circles. Mice were used between 4 and 5 months of age. Data are means $\pm \mathrm{SEM}$; (a) $n=9$, (b) $n=13$, (c) $n=8-9$, (d) $n=9$ $10,(\mathbf{e}, \mathbf{f}) n=7,(\mathbf{g}) n=4$, (h) $n=7-9,(\mathbf{i}, \mathbf{j}) n=5$ animals per group. $* p<$ $0.05, * * * p<0.001$ vs WT. In (h) ${ }^{\dagger} p<0.01$ as shown; $* * * p<0.001$ for the effect of refeeding. In (b), (f) and (g), unpaired two-tailed Student's $t$ test; in (e) and (h), two-way ANOVA with Bonferroni post hoc test

highlighting the role of $M t 1$, rather than $M t 2$, in the negative regulation of insulin secretion.

We also measured the effects of acute stepwise increases in glucose concentration on intracellular $\mathrm{NAD}(\mathrm{P}) \mathrm{H}$ and $\mathrm{Ca}^{2+}$ levels and found no differences between WT and KO islets (Fig. 5g,h). These findings indicate that the potentiation of GSIS in KO islets results from an effect downstream of the stimulation of glucose metabolism and $\mathrm{Ca}^{2+}$ influx.

MTs are known for their metal-binding properties and proposed to play a role in metal ion, including zinc, homeostasis. As zinc plays a key role in beta cell biology, we used Fluozin-3 to compare the dynamic changes in $\left[\mathrm{Zn}^{2+}\right]_{\mathrm{i}}$ in response to glucose and zinc supplementation/chelation in islets from WT and KO mice (ESM Fig. 3a). In islets from both mouse types, $\left[\mathrm{Zn}^{2+}\right]_{\mathrm{i}}$ was increased upon supplementation of $3 \mathrm{mmol} / \mathrm{l}$ glucose-KRB buffer with $10 \mu \mathrm{mol} / 1 \mathrm{ZnCl}_{2}$, slightly decreased upon subsequent stimulation with $30 \mathrm{mmol} / \mathrm{l}$ in the continued presence of $10 \mu \mathrm{mol} / 1 \mathrm{ZnCl}_{2}$, rapidly decreased upon ensuing zinc chelation using TPEN, and markedly increased upon final addition of $1 \mathrm{mmol} / \mathrm{Z} \mathrm{ZnCl} 2$ to the medium. These effects were almost identical in WT and KO islets. In agreement, the mRNA 

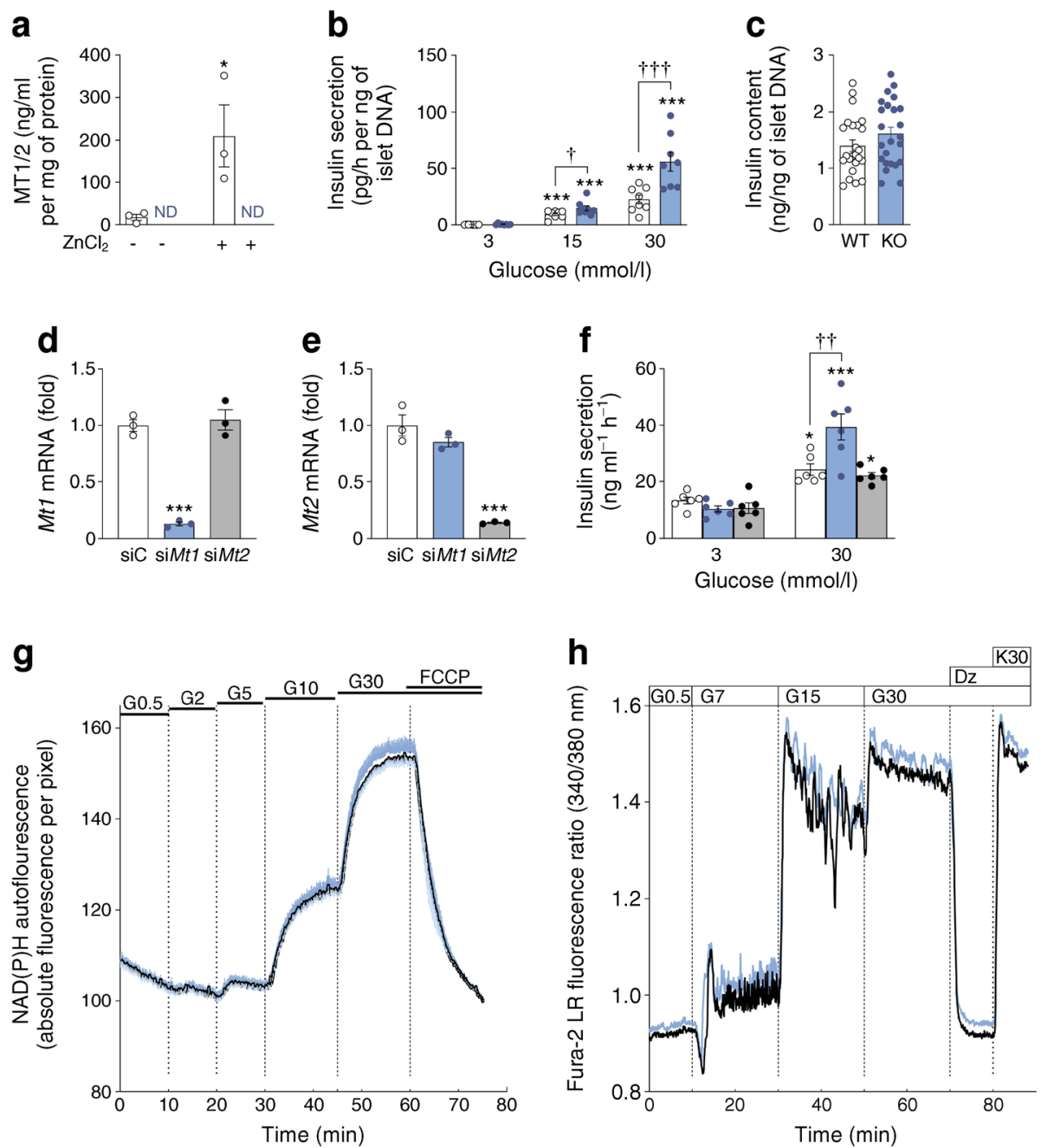

Fig. $5 \mathrm{Mt} 1$ deletion potentiated GSIS. (a) Changes in MT1/MT2 protein levels after $24 \mathrm{~h}$ culture of WT and Mt1-Mt2 double-KO islets in the absence or presence of $100 \mu \mathrm{mol} / / \mathrm{ZnCl}_{2}$. (b) GSIS in WT (white bars) and $\mathrm{KO}$ (blue bars) islets and (c) islet insulin content. (d, e) Changes in the mRNA levels of Mt1 and Mt2 and (f) GSIS in MIN6 cells transfected with either control siRNA (siC; white bars), Mt1 siRNA (siMt1; blue bars) or Mt2 siRNA (siMt2; grey bars). (g) Changes in NAD(P)H autofluorescence normalised for each experiment to the fluorescence level after 15 min treatment with FCCP. (h) Changes in Fura-2 LR fluorescence ratio after $2 \mathrm{~h}$ loading with

levels of the key beta cell zinc transporters Zip6 (also known as Slc39a6), Zip7 (Slc39a7), Znt1 (Slc30a1) and Znt8 (Slc30a8) were similar between KO and WT islets (ESM Fig. 3b-e). These results rule out a potential role of changes in $\left[\mathrm{Zn}^{2+}\right]_{\mathrm{i}}$ levels in the potentiation of GSIS in KO islets.

Assessment of the pancreas morphology revealed no difference in islet architecture between islets from WT and KO mice (ESM Fig. 4a). There were no significant changes in pancreatic weight, beta and alpha cell masses, or the percentage of alpha/beta cells per islet area between $\mathrm{KO}$ and WT mice (ESM Fig. 4b-e). Moreover, islets from WT and KO mice displayed no difference in the mRNA levels of the beta cellenriched genes preproinsulin, $P d x 1$, Glut2 (also known as $S l c 2 a 2$ ), $P c x$ and $G p d 2$ (ESM Fig. 4f-j). Similarly, there were

$2 \mu \mathrm{mol} / /$ of the $\mathrm{Ca}^{2+}$ probe. WT and $\mathrm{KO}$ islets were perifused simultaneously in the same chamber. WT, black traces; KO, blue traces. Data are means \pm SEM. (a) $n=3$ experiments, (b) $n=4$ experiments (in duplicate), (c) $n=24$ islets, (d-f) $n=3$ experiments (f in duplicate), (g) $n=4$ experiments, (h) $n=5$ experiments. $* p<0.05, * * * p<0.001$ for the effect of $\mathrm{ZnCl}_{2}$ or glucose. ${ }^{\dagger} p<0.05,{ }^{\dagger} p<0.01,{ }^{\dagger \dagger} p<0.001$ for the effect of genotype or siRNA. In $(\mathbf{d}, \mathbf{e})$, one-way ANOVA with Newman-Keuls post hoc test; in (a), (b) and (f), two-way ANOVA with Bonferroni post hoc test. Dz, diazoxide; K30, $30 \mathrm{mmol} / \mathrm{K} \mathrm{KCl} ; \mathrm{G} n, n \mathrm{mmol} / \mathrm{l}$ glucose

no changes in the mRNA levels of the endoplasmic reticulum (ER) stress-response genes Hspa 5 and Ddit3 (ESM Fig. 4k,l). Importantly, the deletion of $M t 1$ and $M t 2$ was not compensated for by upregulation of other MT genes. Thus, Mt3 mRNA levels were unchanged in islets from KO vs WT mice (ESM Fig. $4 \mathrm{~m}$ ), while Mt4 mRNA levels were undetected after 40 cycles of PCR amplification in both islet types.

Altogether, these findings strongly support a role for $\mathrm{Mt} 1$ as a negative modulator of GSIS.

Mt1 overexpression attenuated GSIS To further assess the implication of $M t 1$ in the negative regulation of GSIS, we examined islets isolated from global transgenic mice overexpressing mouse $M t 1$ under the control of its natural promoter (Tg-Mtl) 
$[24,25]$. In comparison with WT mice, Tg-Mt1 mice exhibited similar body and liver weights (ESM Fig. 5a-c). They displayed no significant difference in the weight of epidydimal $(p=$ 0.0519), inguinal and retroperitoneal fat pads or the sum of WAT, thereof (ESM Fig. 5d-g). There was also no difference in BAT weight (ESM Fig. 5h). Tg-Mt1 mice also displayed similar fed blood glucose levels (Fig. 6a) and plasma insulin levels (Fig. 6b) to WT mice, and a fasting-refeeding test revealed no significant differences between the two groups (Fig. 6c). Similarly, i.p.GTT tests were similar in 3-month-old and 9month-old animals (Fig. 6d,e). In contrast, i.p.ITT tests revealed a notable difference between WT and Tg-Mt1 mice, with TgMt1 mice displaying lower blood glucose levels during the test (Fig. 6f,g). This effect may stem from an impact of $M t 1$ overexpression on peripheral tissues.

In isolated islets, MT protein levels were markedly upregulated in Tg-Mt1 islets, confirming the overexpression of $\mathrm{Mtl}$ (Fig. 7a). Interestingly, in contrast with its potentiation in KO vs WT islets, GSIS was significantly attenuated in Tg-Mt1 vs WT islets after acute stimulation with $30 \mathrm{mmol} / \mathrm{l}$ glucose (Fig. 7b), while islet insulin content was similar between the two islet types (Fig. 7c). This attenuation in GSIS occurred despite similar rises in intracellular NAD(P)H and $\mathrm{Ca}^{2+}$ levels in islets from WT and $\mathrm{Tg}-\mathrm{Mt1}$ mice in response to stepwise increases in glucose (Fig. 7d,e), indicating that the alteration of GSIS in Tg-
Mt1 mice vs WT mice lies at a step downstream of the stimulation of glucose metabolism and $\mathrm{Ca}^{2+}$ influx.

Similarly, changes in $\left[\mathrm{Zn}^{2+}\right]_{\mathrm{i}}$ in response to glucose and zinc supplementation/chelation were not different between islets from WT and Tg-Mt1 mice (ESM Fig. 6a). In agreement, the mRNA levels of zinc transporters Zip6, Zip7, Znt1 and $Z n t 8$ were unchanged in islets from Tg-Mt 1 mice vs WT mice (ESM Fig. 6b-e).

Importantly, in comparison with islets from WT mice, TgMt1 islets exhibited a similar expression level of the beta cellenriched genes preproinsulin, $P d x 1$, Glut2 and $P c x$ (Fig. 8ad). In addition, the mRNA levels of ER stress-response genes Hspa 5 and Ddit 3 were also not different between the two mouse models (Fig. 8e,f). On the other hand, the overexpression of $M t 1$ (Fig. 8g) resulted in reduced mRNA levels of $M t 2$ $(p<0.05)$ and $M t 3(p=0.0704)$ in comparison with WT islets (Fig. 8h,i), while $M t 4$ mRNA levels were not detected after 40 cycles of PCR amplification in both types of islets.

Collectively, these findings further support the implication of $\mathrm{Mtl}$ in the negative regulation of insulin secretion.

\section{Discussion}

We have unveiled a novel role of $M t 1$ in beta cells as a negative regulator of insulin secretion. The key findings of the
Fig. $6 \mathrm{Mt} 1$ overexpression did not affect glucose tolerance but affected insulin tolerance in vivo. (a) Changes in fed blood glucose levels and (b) fed plasma insulin levels in WT and Tg-Mt1 mice. (c) Changes in blood glucose levels in WT and Tg-Mt1 mice at the fasted state and $1 \mathrm{~h}$ after refeeding. (d, e) Changes in blood glucose levels during an i.p.GTT in overnight-fasted WT and Tg$M t 1$ mice at the age of (d) 3 months and (e) 9 months. (f) Changes in blood glucose levels during an i.p.ITT in $4 \mathrm{~h}$-fasted WT and Tg-Mt1 mice and (g) respective AUC. WT, white bars/circles; Tg- $M t 1$, red bars/circles. Data are means \pm SEM; (a, b) $n=5-6,(\mathbf{d}) n=4,(\mathbf{e})$ $n=6-8$, (f, g) $n=4$ animals per group. $* p<0.05$ for the effect of genotype (f); $* * * p<0.001$ for the effect of refeeding (c), two-way ANOVA with Bonferroni post hoc test. Tg, Tg-Mt1 mice
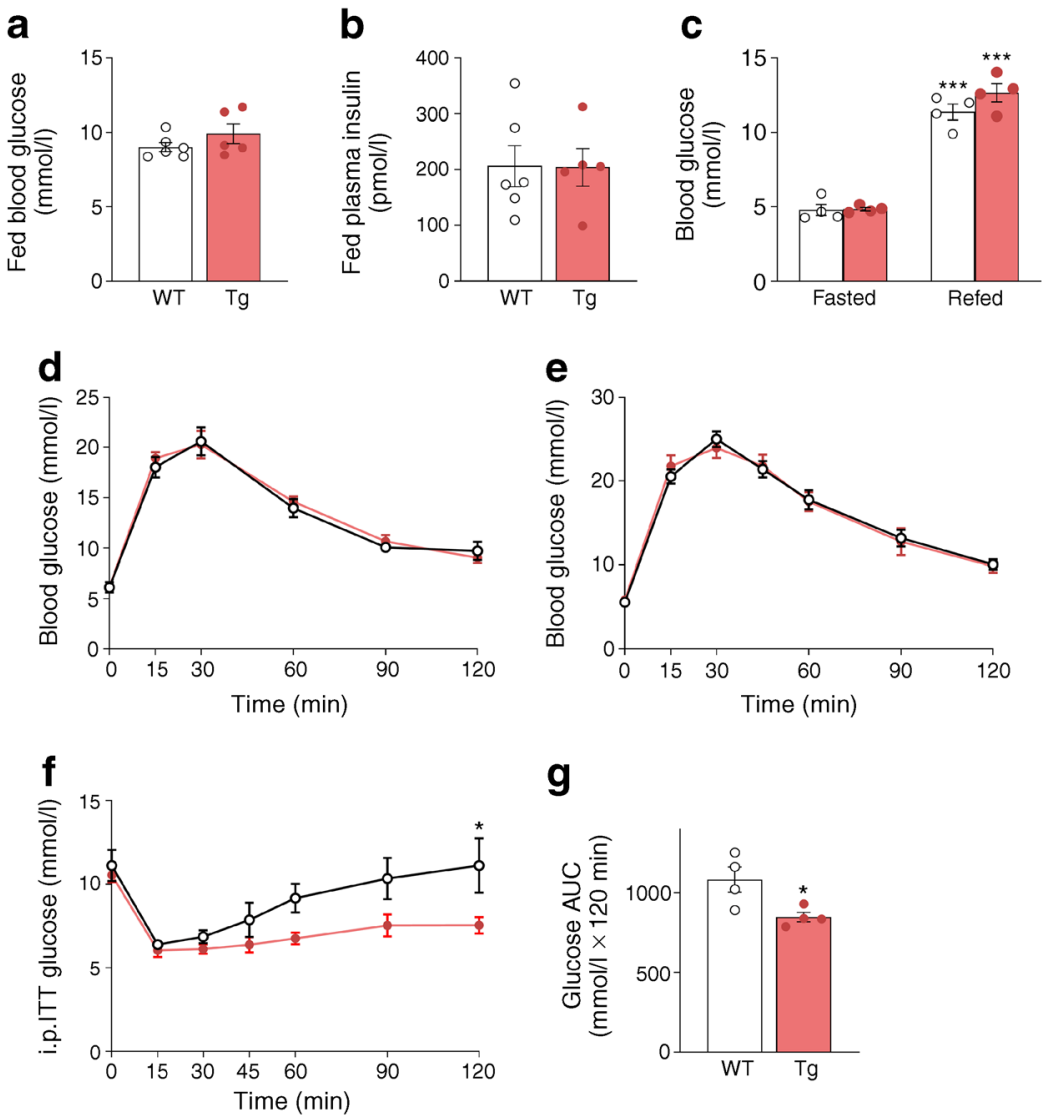

g

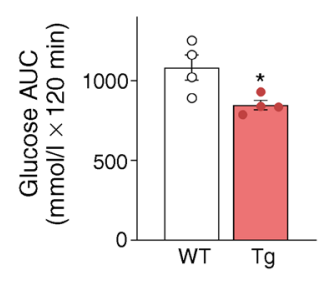



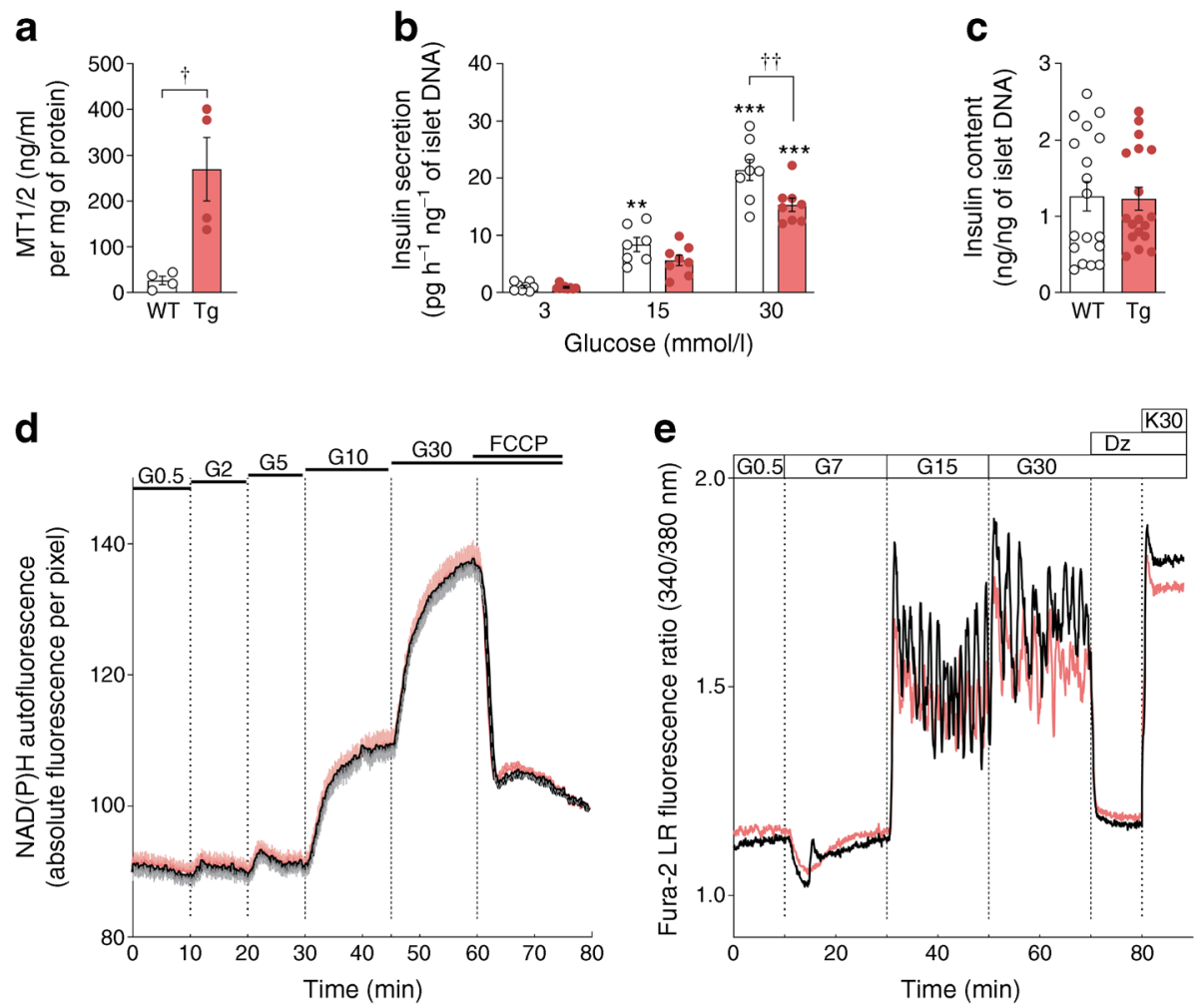

Fig. 7 Mt1 overexpression attenuated GSIS. (a) Changes in MT1/MT2 protein levels in WT and Tg-Mtl islets. (b) GSIS in islets from WT (white bars) and Tg-Mtl (red bars) mice and (c) islet insulin content. (d) Changes in $\mathrm{NAD}(\mathrm{P}) \mathrm{H}$ autofluorescence normalised for each experiment to the fluorescence level after 15 min treatment with FCCP $(n=4)$. (e) Changes in Fura-2 LR fluorescence ratio after $2 \mathrm{~h}$ loading with $2 \mu \mathrm{mol} /$ 1 of the $\mathrm{Ca}^{2+}$ probe $(n=3)$. WT and Tg-Mt1 islets were perifused

simultaneously in the same chamber. WT, black traces; Tg-Mt1, red traces. Data are means \pm SEM. (a, b, d) $n=4$ experiments, (c) $n=18$ islets, (e) $n=3$ experiments. $* * p<0.01, * * * p<0.001$ for the effect of glucose; ${ }^{\dagger} p<0.05,{ }^{\dagger \dagger} p<0.01$ for the effect of genotype. In (a), unpaired two-tailed Student's $t$ test; in (b), two-way ANOVA with Bonferroni post hoc test. Dz, diazoxide; K30, $30 \mathrm{mmol} / 1 \mathrm{KCl} ; \mathrm{G} n, n \mathrm{mmol} / \mathrm{l}$ glucose; $\mathrm{Tg}$, Tg-Mt1 mice

study are: (1) $M t 1$ and $M t 2$ islet gene expression in obese mice was downregulated with beta cell compensation and upregulated with beta cell failure; (2) MTIX islet mRNA levels were upregulated in human type 2 diabetes donors; (3) physiological and supraphysiological glucose stimulation downregulated mouse and human MT islet gene expression; (4) deletion of $M t 1$ and $M t 2$ improved glucose tolerance in vivo and potentiated GSIS in isolated islets; (5) knockdown of MT1, but not MT2, potentiated GSIS in MIN6 cells; and (6) Mt1 overexpression attenuated GSIS in isolated islets (Table 1). These cumulative findings strongly support the implication of $\mathrm{Mt} 1$ in the negative regulation of beta cell function.

\section{$M t 1$ and $M t 2$ exhibit an atypical gene expression pattern in} comparison with other antioxidant genes MTs are known for their protective antioxidant properties [26-28]. Oxidative stress plays an important role in beta cell demise and islets of humans with diabetes and animal models display upregulated expression of many antioxidant genes and markers of oxidative damage [4]. Interestingly, antioxidant genes like Hmoxl, Gpx1, Gpx2, Sod1 and Nrf2 (also known as Nfe2l2) were also upregulated in the islets of compensating young $d b /$ $d b$ mice and mice fed an HFD [17, 29, 30], in sharp contrast

with $M t 1$ and $M t 2$ downregulation (Fig. 1). Similarly, in isolated islets, treatment with glucose upregulated Mt3, Srxn1 and Gpx2, while it downregulated Mt1 and Mt2 (Fig. 2 and $[31,32])$. Noteworthy, our previous studies in Wistar rats revealed that islet $M t 1$ expression was upregulated by fasting and downregulated upon refeeding (J-C Jonas, unpublished data). Furthermore, a recent study exploring beta cell heterogeneity by single-cell transcriptomics revealed that high activity of the insulin gene promoter was associated with low expression of $M t 1$ and $M t 2$ and vice versa [33]. These observations demonstrate that $M t 1$ and $M t 2$ behave differently from other oxidative stress-response genes. Besides, Mt1-Mt2 deletion does not affect antioxidant/stress-response gene expression (ESM Fig. 4 and ESM Fig. 7), indicating no evident impact on islet redox status under physiological conditions. Thus, Mt1 and/or Mt2 may play a role in beta cell (patho)physiology that goes beyond their known antioxidant function.

Mt1 negatively regulates GSIS Deletion of $M t 1$ and $M t 2 \mathrm{im}$ proved glucose tolerance and potentiated GSIS in isolated islets from $\mathrm{KO}$ mice. These findings contrast with a previous study using islets from Mt1-Mt2 KO mice [34]. Although 
a

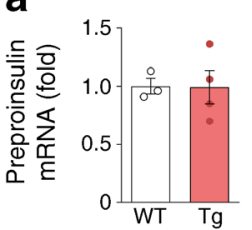

b
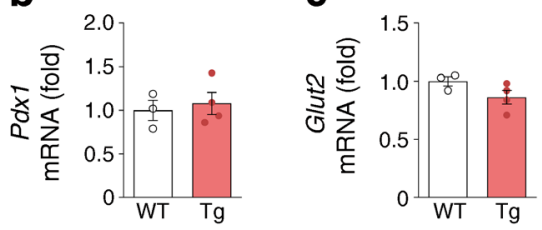

d

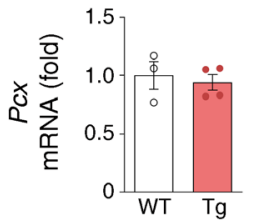

e

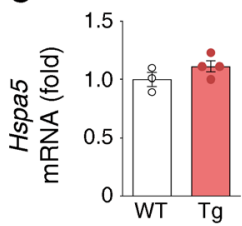

f
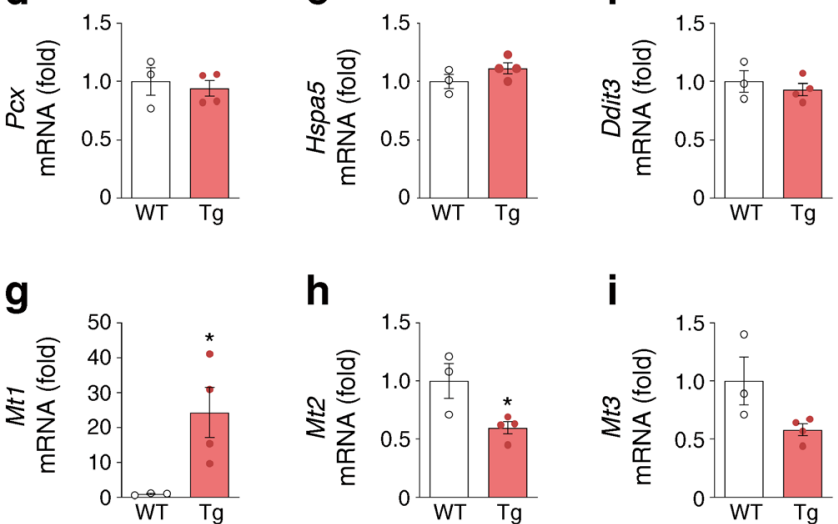

h

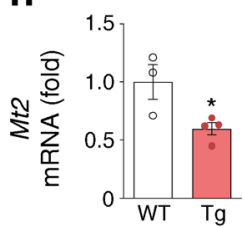

i

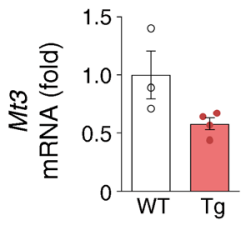

Fig. $8 \mathrm{Mtl}$ overexpression did not affect the expression of beta cellenriched genes and ER stress-response genes. Changes in the mRNA levels of (a-d) preproinsulin, $P d x 1$, Glut2 and $P c x$, and (e, f) ER stressresponse genes Hspa 5 and Ddit3 and (g-i) MT gene isoforms Mt1, Mt2 and $M t 3$. Data are means \pm SEM of $n=3-4$ animals per group. $* p<0.05$ vs WT, unpaired two-tailed Student's $t$ test. Tg, Tg-Mt1 mice

differences in genetic backgrounds may contribute to this discrepancy, our study is more comprehensive than the previous investigation. Thus, besides our complementary in vivo and ex vivo results, the knockdown of MT1 in MIN6 cells reproduced the enhanced insulin secretory phenotype of the $\mathrm{KO}$ islets. Furthermore, in our study, islets overexpressing $M t 1$ exhibited the reciprocal phenotype.

Our results underscore the role of $M t 1$, rather than $M t 2$, in the modulation of insulin secretion. Although these genes exhibit similar expression patterns, $M t 1$ displays a higher expression level in comparison with $M t 2$ and $M t 3$ in primary mouse islets (ESM Fig. 8). In addition, mRNA sequence alignment analysis showed that $M t 1$ and $M t 2$ are only $\sim 80 \%$ identical.

Thus, the $\sim 20 \%$ sequence difference may also underlie functional specificities. Such specificities may stem from different metal affinities and binding properties or from specific protein-protein interactions $[6,35]$.

How could $M t 1$ impact on insulin secretion? We did not detect significant changes in classical metabolic $(\mathrm{NAD}(\mathrm{P}) \mathrm{H})$ and ionic parameters (cytosolic free $\mathrm{Ca}^{2+}$ and $\mathrm{Zn}^{2+}$ ) in response to glucose stimulation between islets from WT mice and $\mathrm{KO}$ or Tg-Mtlmice. The expression of antioxidant and other stress-response genes was not different between WT and KO islets, thereby ruling out a potential impact on redox status (ESM Fig. 4 and ESM Fig. 7). Furthermore, Mt1-Mt2 deletion or $M t 1$ overexpression had no impact on cell death in islets cultured under control conditions $(10 \mathrm{mmol} / 1$ glucose; ESM Fig. 9). Nevertheless, insulin secretion in response to high potassium was also potentiated in islets from $\mathrm{KO}$ vs WT mice (ESM Fig. 10). This result strongly suggests a potential impact of $M t 1$ on the beta cell exocytotic machinery. Interestingly, MT3 was previously shown to interact with Rab3A GTPase in neurons, thereby playing a role in presynaptic vesicle trafficking [36]. One may, therefore, hypothesise that MT1 interacts with a yet-to-be-identified protein of the beta cell exocytotic machinery to modulate insulin secretion.

The mechanism(s) of induction of $M t 1$ in diabetes Hyperglycaemia, per se, may not be the upstream factor involved in increased expression of Mtl in diabetes. Indeed, although $M t 1$ mRNA expression transiently increases in rat islets cultured overnight with glucose at $30 \mathrm{mmol} / 1 \mathrm{vs}$ $10 \mathrm{mmol} / \mathrm{l}$ [16], prolonged exposure of mouse and rat islets to high glucose $(30 \mathrm{mmol} / \mathrm{l})$ had little or no impact (vs $10 \mathrm{mmol} / \mathrm{l})$ on $\mathrm{Mt} 1$ and $M t 2 \mathrm{mRNA}$ and MT1/MT2 protein levels (Fig. 2 and [32]). In human islets, culture in the presence of the already supraphysiological glucose concentration of $11.1 \mathrm{mmol} / \mathrm{l}$ vs 2.2 and $5.5 \mathrm{mmol} / \mathrm{l}$ also downregulated the mRNA levels of MT genes. Upregulation beyond this concentration may result from differences in glucose sensitivity and
Table 1 Overview of the principal findings of the study

\begin{tabular}{lllllll}
\hline Species & Gene & $\begin{array}{l}\text { Expression during } \\
\text { beta cell } \\
\text { compensation }\end{array}$ & $\begin{array}{l}\text { Expression } \\
\text { in T2D }\end{array}$ & $\begin{array}{l}\text { Glucose effect } \\
\text { on expression } \\
\text { ex vivo }\end{array}$ & $\begin{array}{l}\text { Effect of } \\
\text { deletion/KD } \\
\text { on GSIS }\end{array}$ & $\begin{array}{l}\text { Effect of } \\
\text { overexpression } \\
\text { on GSIS }\end{array}$ \\
\hline Mouse & $M t 1$ & $\downarrow$ & $\uparrow$ & $\downarrow(\mathrm{G} 2-\mathrm{G} 30)$ & $\uparrow$ & $\downarrow$ \\
Human & $M t 2$ & $\downarrow$ & $\uparrow$ & $\downarrow(\mathrm{G} 2-\mathrm{G} 30)$ & $\leftrightarrow$ & $\mathrm{ND}$ \\
& $M T 1 E$ & $\mathrm{ND}$ & $\leftrightarrow$ & $\downarrow(\mathrm{G} 2.2-\mathrm{G} 11.1)$ & $\mathrm{ND}$ & $\mathrm{ND}$ \\
& $M T 1 X$ & $\mathrm{ND}$ & $\uparrow$ & $\downarrow(\mathrm{G} 2.2-\mathrm{G} 11.1)$ & $\mathrm{ND}$ & $\mathrm{ND}$ \\
& $M T 2 A$ & $\mathrm{ND}$ & $\leftrightarrow$ & $\downarrow(\mathrm{G} 2.2-\mathrm{G} 11.1)$ & $\mathrm{ND}$ & $\mathrm{ND}$ \\
\hline
\end{tabular}

$\uparrow$, increased; $\downarrow$, decreased; $\leftrightarrow$, no change; $\mathrm{G} n, n$ mmol/l glucose; KD, knockdown; ND, not determined; T2D, type 2 diabetes

The two glucose concentrations given between parentheses indicate the range within which the downregulation occurs 
metabolism between human and mouse islets and may involve the activation of glucotoxicity-related pathways [4]. We have previously shown that rat islet $M t 1$ expression is markedly induced by exogenous $\mathrm{H}_{2} \mathrm{O}_{2}$, the sarcoendoplasmic reticulum $\mathrm{Ca}^{2+}$-ATPase (SERCA) pump inhibitor thapsigargin, the cytokine IL-1 $\beta$ and hypoxia [37]. However, the islet expression of genes induced by oxidative stress, ER stress and inflammatory stress are observed in the prediabetic stage in $d b / d b$ mice [17], suggesting alternate mechanisms. On the other hand, evidence from several studies implicates a possible role of hypoxia: Mt1 mRNA expression is upregulated by hypoxia in mouse and human islets (ESM Fig. 11 and [38]), and a clear temporal in vivo association is observed between MT expression and an hypoxic gene expression signature in islets of $d b /$ $d b$ mice $[39,40]$.

Limitations of the study and perspectives In this study, we used global KO animals. Since Mt1-Mt2 deletion may affect other metabolic tissues, one may argue that the observed secretory phenotype involves the effect of systemic factors. However, this is unlikely as we systematically precultured isolated islets for 1 week before GSIS tests. We also combined different models to demonstrate that $M t 1$ negatively regulates insulin secretion, i.e. by confirming the secretory phenotype after MT1 knockdown in MIN6 cells. Additionally, the attenuation of GSIS by $M t 1$ overexpression further supports our hypothesis. Although the Tg-Mt1 model is also global, it presents two important advantages: (1) the overexpression of the mouse Mt1 gene rather than human MT2A gene [41]; and (2) the control of $M t 1$ by its natural promoter rather than the insulin promoter, thereby avoiding the ER stress and oxidative stress observed in MT2A-transgenic mice [41]. Indeed, our Tg-Mt1 islets displayed normal expression of ER stressresponse genes (Fig. 8). Nevertheless, development of an $M t 1$-floxed mouse model is warranted for further exploration of these novel roles of $M t 1$ in beta cell biology.

Conclusion $\mathrm{Mt1}$ negatively regulates insulin secretion. Downregulation of islet $\mathrm{Mt} 1$ in obesity may, thus, contribute to beta cell compensation, and its upregulation in type 2 diabetes may contribute to beta cell failure. Inhibition of $M t 1$ may, therefore, represent an attractive therapeutic target to preserve and restore insulin secretion in type 2 diabetes.

\footnotetext{
Acknowledgements We thank F. Knockaert (UCLouvain, Belgium) for expert technical help and J.-C. Henquin (UCLouvain, Belgium) for valuable discussion and suggestions. We also thank J. Duprez (UCLouvain, Belgium) for pilot experiments carried out in $M t$-KO mice. Some of the data were presented as an abstract at the 54th EASD meeting in Berlin, Germany, 1-5 October 2018.
}

Data availability All data points generated or analysed during the current study are shown in the figures of this published article (and its supplementary information files). Tabulated datasets are available from the corresponding author on reasonable request.
Funding MB was supported by a MOVE-in Louvain/EC Marie-Curie incoming postdoctoral fellowship and is currently supported by a fellowship from the 'Fonds de Recherche Clinique', Cliniques Universitaires Saint-Luc, Brussels, Belgium. This work was supported by a grant from the Société Francophone du Diabète, Paris, France (SFD/MSD 2016), the Action de Recherche Concertée 12/17-047 from the Communauté française de Belgique, and the 'Fonds Spécial de Recherche 2016' from UCLouvain to JCJ. JCJ and PG are Research Directors of the Fonds de la Recherche Scientifique-FNRS, Belgium. JYC is supported by an NHMRC Early Career Fellowship. DRL is supported by an Australian Research Council (ARC) Future Fellowship. St Vincent's Institute receives support from the Operational Infrastructure Support Scheme of the Government of Victoria.

Duality of interest The authors declare that there is no duality of interest associated with this manuscript.

Contribution statement MB conceived the study and designed experiments, acquired and analysed most of the data and wrote the first draft of the manuscript. JCJ conceived the study and designed experiments, analysed data and revised the manuscript. YCS, JYC, DRL, HC, MAS, EGP and HET designed experiments, acquired and analysed data and critically reviewed the manuscript. PG contributed to the analysis and interpretation of the data and critically reviewed the manuscript. All authors approved the final version of the manuscript. MB is the guarantor of this work.

\section{References}

1. Weyer C, Bogardus C, Mott DM, Pratley RE (1999) The natural history of insulin secretory dysfunction and insulin resistance in the pathogenesis of type 2 diabetes mellitus. J Clin Invest 104(6):787794. https://doi.org/10.1172/JCI7231

2. Pratley RE, Weyer C (2002) Progression from IGT to type 2 diabetes mellitus: the central role of impaired early insulin secretion. Curr Diab Rep 2(3):242-248. https://doi.org/10.1007/s11892-0020090-6

3. Kahn SE (2003) The relative contributions of insulin resistance and beta-cell dysfunction to the pathophysiology of type 2 diabetes. Diabetologia 46(1):3-19. https://doi.org/10.1007/s00125-0021009-0

4. Bensellam M, Laybutt DR, Jonas JC (2012) The molecular mechanisms of pancreatic beta-cell glucotoxicity: recent findings and future research directions. Mol Cell Endocrinol 364(1-2):1-27. https://doi.org/10.1016/j.mce.2012.08.003

5. Bensellam M, Jonas JC, Laybutt DR (2018) Mechanisms of betacell dedifferentiation in diabetes: recent findings and future research directions. J Endocrinol 236(2):R109-R143. https://doi.org/10. 1530/JOE-17-0516

6. Zalewska M, Trefon J, Milnerowicz H (2014) The role of metallothionein interactions with other proteins. Proteomics 14(11):13431356. https://doi.org/10.1002/pmic.201300496

7. Kimura T, Kambe T (2016) The functions of metallothionein and ZIP and ZnT transporters: an overview and perspective. Int J Mol Sci 17(3):336. https://doi.org/10.3390/ijms17030336

8. Giacconi R, Bonfigli AR, Testa R et al (2008) $+647 \mathrm{~A} / \mathrm{C}$ and +1245 MT1A polymorphisms in the susceptibility of diabetes mellitus and cardiovascular complications. Mol Genet Metab 94(1):98-104. https://doi.org/10.1016/j.ymgme.2007.12.006

9. Yang L, Li H, Yu T et al (2008) Polymorphisms in metallothionein1 and -2 genes associated with the risk of type 2 diabetes mellitus 
and its complications. Am J Physiol Endocrinol Metab 294(5): E987-E992. https://doi.org/10.1152/ajpendo.90234.2008

10. Raudenska M, Gumulec J, Podlaha O et al (2014) Metallothionein polymorphisms in pathological processes. Metallomics 6(1):55-68. https://doi.org/10.1039/C3MT00132F

11. Marselli L, Thorne J, Dahiya S et al (2010) Gene expression profiles of Beta-cell enriched tissue obtained by laser capture microdissection from subjects with type 2 diabetes. PLoS One 5(7):e11499. https://doi.org/10.1371/journal.pone.0011499

12. O'Connell PJ, Holmes-Walker DJ, Goodman D et al (2013) Multicenter Australian trial of islet transplantation: improving accessibility and outcomes. Am J Transplant 13(7):1850-1858. https://doi.org/10.1111/ajt.12250

13. Bensellam M, Montgomery MK, Luzuriaga J, Chan JY, Laybutt DR (2015) Inhibitor of differentiation proteins protect against oxidative stress by regulating the antioxidant-mitochondrial response in mouse beta cells. Diabetologia 58(4):758-770. https://doi.org/ 10.1007/s00125-015-3503-1

14. Shi YC, Loh K, Bensellam M et al (2015) Pancreatic PYY is critical in the control of insulin secretion and glucose homeostasis in female mice. Endocrinology 156(9):3122-3136. https://doi.org/10.1210/ en.2015-1168

15. Miyazaki J, Araki K, Yamato E et al (1990) Establishment of a pancreatic beta cell line that retains glucose-inducible insulin secretion: special reference to expression of glucose transporter isoforms. Endocrinology 127(1):126-132. https://doi.org/10.1210/endo-127$1-126$

16. Bensellam M, Van Lommel L, Overbergh L, Schuit FC, Jonas JC (2009) Cluster analysis of rat pancreatic islet gene mRNA levels after culture in low-, intermediate- and high-glucose concentrations. Diabetologia 52(3):463-476. https://doi.org/10.1007/s00125-0081245-Z

17. Chan JY, Luzuriaga J, Bensellam M, Biden TJ, Laybutt DR (2013) Failure of the adaptive unfolded protein response in islets of obese mice is linked with abnormalities in beta-cell gene expression and progression to diabetes. Diabetes 62(5):1557-1568. https://doi.org/ $10.2337 / \mathrm{db} 12-0701$

18. Chan JY, Luzuriaga J, Maxwell EL, West PK, Bensellam M, Laybutt DR (2015) The balance between adaptive and apoptotic unfolded protein responses regulates beta-cell death under ER stress conditions through XBP1, CHOP and JNK. Mol Cell Endocrinol 413:189-201. https://doi.org/10.1016/j.mce.2015.06. 025

19. Andersson A (1978) Isolated mouse pancreatic islets in culture: effects of serum and different culture media on the insulin production of the islets. Diabetologia 14(6):397-404. https://doi.org/10. 1007/BF01228134

20. Ling Z, Pipeleers DG (1994) Preservation of glucose-responsive islet beta-cells during serum-free culture. Endocrinology 134(6): 2614-2621. https://doi.org/10.1210/endo.134.6.7515006

21. Eizirik DL, Korbutt GS, Hellerstrom C (1992) Prolonged exposure of human pancreatic islets to high glucose concentrations in vitro impairs the beta-cell function. J Clin Invest 90(4):1263-1268. https://doi.org/10.1172/JCI115989

22. Ling Z, Pipeleers DG (1996) Prolonged exposure of human beta cells to elevated glucose levels results in sustained cellular activation leading to a loss of glucose regulation. J Clin Invest 98(12): 2805-2812. https://doi.org/10.1172/JCI119108

23. Masters BA, Kelly EJ, Quaife CJ, Brinster RL, Palmiter RD (1994) Targeted disruption of metallothionein I and II genes increases sensitivity to cadmium. Proc Natl Acad Sci U S A 91(2):584-588. https://doi.org/10.1073/pnas.91.2.584

24. Palmiter RD, Sandgren EP, Koeller DM, Brinster RL (1993) Distal regulatory elements from the mouse metallothionein locus stimulate gene expression in transgenic mice. Mol Cell Biol 13(9):52665275. https://doi.org/10.1128/MCB.13.9.5266
25. Iszard MB, Liu J, Liu Y et al (1995) Characterization of metallothionein-I-transgenic mice. Toxicol Appl Pharmacol 133(2):305-312. https://doi.org/10.1006/taap.1995.1155

26. Chen H, Carlson EC, Pellet L, Moritz JT, Epstein PN (2001) Overexpression of metallothionein in pancreatic beta-cells reduces streptozotocin-induced DNA damage and diabetes. Diabetes 50(9):2040-2046. https://doi.org/10.2337/diabetes. 50.9.2040

27. Li X, Chen H, Epstein PN (2004) Metallothionein protects islets from hypoxia and extends islet graft survival by scavenging most kinds of reactive oxygen species. J Biol Chem 279(1):765-771. https://doi.org/10.1074/jbc.M307907200

28. Li X, Chen H, Epstein PN (2006) Metallothionein and catalase sensitize to diabetes in nonobese diabetic mice: reactive oxygen species may have a protective role in pancreatic beta-cells. Diabetes 55(6):1592-1604. https://doi.org/10.2337/ $\mathrm{db} 05-1357$

29. Roat R, Rao V, Doliba NM et al (2014) Alterations of pancreatic islet structure, metabolism and gene expression in diet-induced obese C57BL/6J mice. PLoS One 9(2):e86815. https://doi.org/10. 1371/journal.pone.0086815

30. Hatanaka M, Anderson-Baucum E, Lakhter A et al (2017) Chronic high fat feeding restricts islet mRNA translation initiation independently of ER stress via DNA damage and p53 activation. Sci Rep 7(1):3758. https://doi.org/10.1038/s41598-017-03869-5

31. Bellomo EA, Meur G, Rutter GA (2011) Glucose regulates free cytosolic $\mathrm{Zn}(2)(+)$ concentration, Slc39 (ZiP), and metallothionein gene expression in primary pancreatic islet beta-cells. J Biol Chem 286(29):25778-25789. https://doi.org/ 10.1074/jbc.M111.246082

32. Duprez J, Roma LP, Close AF, Jonas JC (2012) Protective antioxidant and antiapoptotic effects of $\mathrm{ZnCl} 2$ in rat pancreatic islets cultured in low and high glucose concentrations. PLoS One 7(10): e46831. https://doi.org/10.1371/journal.pone.0046831

33. Modi HCH, Skovsø S, Hu X, et al (2018) Imaging Ins2 gene activity and single-cell RNA sequencing reveal heterogeneous beta cell states. In: Diabetologia (ed) 54th EASD Annual Meeting of the European Association for the Study of Diabetes. Springer Berlin Heidelberg, Berlin, Germany, p 17

34. Laychock SG, Duzen J, Simpkins CO (2000) Metallothionein induction in islets of Langerhans and insulinoma cells. Mol Cell Endocrinol 165(1-2):179-187. https://doi.org/10.1016/S03037207(00)00247-1

35. Artells E, Palacios O, Capdevila M, Atrian S (2013) Mammalian MT1 and MT2 metallothioneins differ in their metal binding abilities. Metallomics 5(10):1397-1410. https://doi.org/10.1039/ c3mt00123g

36. Knipp M, Meloni G, Roschitzki B, Vasak M (2005) Zn7metallothionein-3 and the synaptic vesicle cycle: interaction of metallothionein-3 with the small GTPase Rab3A. Biochemistry 44(9):3159-3165. https://doi.org/10.1021/ bi047636d

37. Jonas JC, Bensellam M, Duprez J, Elouil H, Guiot Y, Pascal SM (2009) Glucose regulation of islet stress responses and beta-cell failure in type 2 diabetes. Diabetes Obes Metab 11(Suppl 4):6581. https://doi.org/10.1111/j.1463-1326.2009.01112.x

38. Gerber PA, Bellomo EA, Hodson DJ et al (2014) Hypoxia lowers SLC30A8/ZnT8 expression and free cytosolic $\mathrm{Zn} 2+$ in pancreatic beta cells. Diabetologia 57(8):1635-1644. https://doi.org/10.1007/ s00125-014-3266-0

39. Bensellam M, Duvillie B, Rybachuk G et al (2012) Glucoseinduced $\mathrm{O}(2)$ consumption activates hypoxia inducible factors 1 and 2 in rat insulin-secreting pancreatic beta-cells. PLoS One 7(1):e29807. https://doi.org/10.1371/journal.pone.0029807

40. Bensellam M, Maxwell EL, Chan JY et al (2016) Hypoxia reduces ER-to-Golgi protein trafficking and increases cell 
death by inhibiting the adaptive unfolded protein response in mouse beta cells. Diabetologia 59(7):1492-1502. https://doi. org/10.1007/s00125-016-3947-y

41. Chen S, Han J, Liu Y (2015) Dual opposing roles of metallothionein overexpression in C57BL/6J mouse pancreatic beta-cells.
PLoS One 10(9):e0137583. https://doi.org/10.1371/journal.pone. 0137583

Publisher's note Springer Nature remains neutral with regard to jurisdictional claims in published maps and institutional affiliations. 